\title{
ЯВИЩЕ МОВНОЇ ВЗАЕМОДІї: ДОСЛІДНИЦЬКІ ПІДХОДИ, СПЕЦИФІКА ТРАКТУВАННЯ, ПРИЧИНИ
}

\author{
ГАЛИНА НАМАЧИНСЬКА \\ Дрогобицький державний педагогічний університет імені Івана Франка, \\ Дрогобич - Україна \\ fokysnam@ukr.net \\ ZJAWISKO INTERAKCJI WERBALNEJ: \\ PODEJŚCIA BADAWCZE, \\ SPECYFIKA UJĘCIA, PRZYCZYNY WYSTĘPOWANIA \\ HAŁYNA NAMACZYNSKA \\ Państwowy Uniwersytet Pedagogiczny imienia Iwana Franki w Drohobyczu, Drohobycz - \\ Ukraina
}

STRESZCZENIE. Zmiany spowodowane rozwojem współpracy technicznej, gospodarczej i politycznej, a także więzi kulturowe między poszczególnymi krajami świata generują wzajemne związki między językami. W konsekwencji takiej komunikacji pojawiają się różnego rodzaju zapożyczenia. Wynika potrzeba dokładnego zbadania zjawiska interakcji werbalnej, rozważenia specyfiki interpretacji terminów oraz ukazania powodów zapożyczeń. Artykuł poświęcono wyżej wymienionym zagadnieniom.

\section{PHENOMENON OF VERBAL INTERACTION: RESEARCH APPROACH, SPECIFIC TREATMENT, CAUSES}

\author{
HALYNA NAMACHYNSKA \\ Drohobych Ivan Franko State Pedagogical University, Drohobych — Ukraine
}

ABSTRACT. The changes caused by the development of technical, economic and political cooperation between the world cultural relations reflect active contacts of languages. As a result of these contacts borrowings appear. There is a need to explore in details the phenomenon of a verbal interaction, to consider the specific interpretation of the terms and describe the reasons for borrowing. This problem is analyzed in the article.

$\mathrm{H}$

е існує мови, що була б цілком ізольована від інших мов, відірвана від інших культур. Мова як живий витвір, креативна система постійно збагачується, зокрема й унаслідок переміщення ії елементів з однієї мови до іншої, через відповідне взаємопроникнення, взаємозбагачення чи, навпаки, засмічення. Цей процес аксіологічно протиставляють як позитивний і як негативний залежно від векторів його чинності.

Актуалізоване в цій праці мовне явище привертає прискіпливу увагу лінгвістів, оскільки процес запозичення відбувається безперервно. Питання методології вивчення запозичень, їхньої класифікації, розгляд і трактування явищ, що безпосередньо пов'язані з ними, стосуються їхнього функціювання i под., а також питання стосовно формування відповідного дослідницького термінологічного апарата, методів та методик вивчення вказаного явища, торка- 
лися класики українського (Л. Булаховський, І. Огієнко, О. Потебня, В. Сімович, Ю. Шевельов, І. Франко та ін.) та зарубіжного (У. Вайнайрх, Я. Грот, В. фон Гумбольдт, Ф. де Соссюр, Л. Щерба та ін.) мовознавства.

Мета цієї статті - описати причини мовної взаємодії, а також специфіку трактування цього явища в науковій лінгвістичній літературі та проаналізувати систему дослідницьких підходів до вивчення цього явища.

Наголосимо, що всі процеси взаємовпливу мов, відповідно, відбуваються за певними законами. Щоб краще їх проілюструвати, Ф. де Соссюр удало порівнював мовну систему з грою в шахи. На прикладі, який навів учений, легко можна усвідомити, що належить до закономірного, а що - до випадкового: те, що ця гра прийшла до Європи з Персії, факт зовнішній; навпаки, внутрішнє становить усе те, що стосується системи та правил. Якщо замінити дерев'яні фігури на фігури зі слонової кістки, то ця заміна буде байдужою для системи; коли ж зменшити чи збільшити кількість фігур, така зміна глибоко зачепить “граматику гри”.

Представники празької лінгвістичної школи, до речі, погоджуючись із “соссюрівським” порівнянням, додають, що „гра в шахи - не примітивна”. Вона дуже змістовна й оригінальна через те, що, ураховуючи відповідні правила, гравець повинен постійно ними маніпулювати, мислити, удосконалювати можливості гри, хоч чітко окреслених і прийнятих іiї правил необхідно послідовно дотримуватися, „щоб партія від початку до кінця була вдалою”2.

Отже, мовна взаємодія не повинна руйнувати системи контактних мов, а це значить, що вводити в мовлення чужі звуки, слова чи словосполучення іншої мови необхідно обережно, не руйнуючи ії граматичної основи, фонетичних та орфоепічних особливостей, оберігаючи її красу, активізувавши ії власне лексико-фразеологічне багатство.

Натомість довільне змішування слів і словосполучень взаємодіючих мов, відмінювання відповідних мовних одиниць за зразком чужої мови, творення фраз усупереч моделям рідної мови і под. неприпустимез

Термін "мовний контакт" був запропонований У. Вайнайрхом, порівн.: „...дві або кілька мов перебувають у контакті, якщо ними поперемінно користується та сама особа. Таким чином, місцем здійснення контакту $\epsilon$ індивіди, які користуються мовою"4. Праця У. Вайнрайха Мовні контак$m u$ - це підсумок багаторічним дискусіям навколо проблеми змішування мов. Для окреслення цього поняття мовознавці використовують низку термінів, як-от: “мовленнєве спілкування між двома мовними колективами", "зіткнення мов, що виникає внаслідок особливих географічних, історичних та соціальних умов, які приводять до необхідності мовного спілкування людських колективів, що спілкуються різними мовами”, 6 “схрещування мов”, “іншомовний вплив”, “змішування мов”, “взаємовплив мов”, “мовна взаємодія”, “мовні контакти”. Кожен із цих термінів, як стверджують лінгвісти, додає нові аспекти до розуміння явища.

\footnotetext{
${ }^{1}$ Див.: Фердинанд де Соссюр, Курс загальної лінгвістики, Київ 1998.

${ }^{2}$ Й. В ах ек, Лингвистический словарь пражской школь, Москва 1964, с. 268.

${ }^{3}$ Антисуржск. Вчимося ввічливо поводитись і правильно говорити, за заг. ред. О. Сербен ської, Львів 1994, с. 6.

${ }^{4}$ У. В Вйн райх, Языковые контакты. Состояние и проблемы решения, Київ 1979, с. 262.

${ }_{5}^{5}$ В. Ю. Розенцвейг, Языковые контакты. Лингвистическая проблематика, Ленинград 1972, c. 3.

${ }^{6}$ О. С. Ахманова, Словарь лингвистических терминов, Москва 1966, с. 535.
} 
Наголосимо, що дещо нелогічним уважають мовознавці для окреслення явища взаємодії мов використання терміна "мішана мова", оскільки він указує на наслідок негативної взаємодії, тобто інтерференцію, виключаючи трансференцію: у цьому разі певна мова стає результатом змішування мов не в рівних пропорціях, одна з мов починає домінувати, насаджати свої елементи іншій.

Л. Щерба ввів термін — “взаємний вплив мов"7, що ввійшов в лінгвістичний обіг і слугує для окреслення, власне, явища взаємного впливу, а не однобічного.

Найуживанішими термінологічними сполученнями для номінації розглядуваного явища без конкретизації характеру взаємовпливу в мовознавстві сьогодні прийнято два: “взаємодія мов" та "мовні контакти".

Учені пропонують систему визначень для розглядуваного явища, але актуалізують різні підходи. Хоч певна група дослідників уважає наведені вище терміни синонімами, інші ж їх розрізняють: під взаємодією мов розуміють комплекс явищ, що виникає внаслідок міжмовних зв'язків, а мовні контакти визначають як певний тип міжмовних зв'язків, що, відповідно, поділяють на (а) дистантні (від лат. distantia - відстань), коли відсутні двомовність і прямий контакт носіїв мов, що взаємодіють, та (б) інтермедіарні (від лат. intermedius - проміжний, середній) - міжмовні зв'язки, які виникають між двома мовами, що безпосередньо не контактують, але кожна з них $є$ в контакті з третьою мовою як мовою-посередником 8 .

С. Семчинський дає точне, як видається, визначення поняття "мовні контакти”: „Це взаємодія двох і більше мов, коли висловлювання однією мовою включають до свого складу елементи іншої мови, або, навпаки, - висловлювання другою мовою включають до свого складу елементи першої мови"я.

У російському лінгвістичному енциклопедичному словнику зазначено, що мовні контакти (від лат. contactus - дотик) — „це взаємодія двох чи більше мов, що впливає на структуру словника одної чи багатьох з них" ${ }^{\text {. }}$. В українському виданні Словник сучасної лінгвістики: поняття $і$ терміни А. Загнітко подає таке визначення: „Контакти (лат. contactus - доторкання) мовні - взаємодія двох або більшої кількості мов, що впливає на граматичну структуру і словник однієї або багатьох із них. Соціальні умови К. м. - спілкування між особистостями різних національних лінгвокультурних спільнот" ${ }^{11}$. Пошук найбільш точного визначення поняття “мовні контакти”, як бачимо, триває.

Загальновизнаним на сьогодні стало твердження, що мовні зміни не відбуваються довільно. Вони завжди мають причини - внутрішні чи зовнішні. Зовнішні причини мотивовані, звісно, тими імпульсами мовного розвитку, що надходять 3 довкілля, а до внутрішніх тенденцій мовного розвитку відносять такі, що закладені в самій мові, зокрема і Л. Щерба вважав запозичення не тільки наслідком міжмовних процесів, але й внутрішньомовних. Учений зазначає, що ,запозичення можуть приходити не тільки з чужих мов, але й 3 діалектів, зокрема як з географічних, так особливо і з соціальних"12.

\footnotetext{
${ }^{7}$ Л. В. Щерба, О понятии смешения языков, Ленинград 1974, с. 60.

${ }^{8}$ С. В. Се мчин сь кий, Загальне мовознавство, Київ 1988, с. 274.

${ }^{9}$ Там само, с. 273.

${ }^{10}$ Лингвистический энциклопедический словарь, под ред. В. Н. Ярцевой, Москва 1990, c. 273.

${ }^{11}$ А. Загнітко, Словник сучасної лінгвістики: поняття і терміни, Донецьк 2012, с. 89. c. $56-62$.

${ }_{12}$ Л. В. Щерба, Безграмотность и ее причины, [в:] Избр. раб. по рус. яз., Москва, 1957,
} 
У мові кожного народу, безперечно, виявляються зміни, що є наслідком мовного контактування. Не існує мови, що не зазнала б впливу довкілля: „всі мови більшою або меншою мірою становлять продукти змішування (злиття)"'13.

Якими ж є зовнішні причини запозичень?

М. Кочерган уважає, що мовні контакти мають місце в разі таких зовнішніх чинників, як: „1) загарбання території і поневолення корінного етносу; 2) коли на одній території мирно співіснує відповідне населення; 3) коли населення вступає в різноманітні (економічні, торговельні, культурні та інші) стосунки 3 населенням іншої країни; 4) коли засвоюється інша мова в процесі шкільного навчання" 14 . Учений виокремлює внутрішні чинники, що стимулюють входження запозичених лексем: 1) намагання уникнути полісемії, закріпити за своїм і чужим словом різні смислові відтінки; 2) прагнення замінити багатослівне найменування однослівним ${ }^{15}$.

Досліджуючи запозичення, С. Семчинський виокремлює такі чинники цього процесу: 1) нелінгвістичні або екстралінгвістичні; 2) лінгвістичні: зовнішні (інтерлінгвістичні) та внутрішні (інтралінгвістичні) ${ }^{16}$. Деякі лінгвісти іменують ïx „екстра- та інтралінгвальними” (О. Ахманова, В. Панфілов), “нелінгвальними” (Ю. Гепнер). І. Кочан дає їм іншу назву: “зовнішньо- та внутрішньомовні чинники, під впливом яких запозичуються іншомовні слова" ${ }^{17}$. Дослідниця підкреслює, що „з давніх-давен торговельні, економічні та культурні зв'язки між народами сприяли проникненню в різні мови іншомовних слів. Запозичували слова на позначення реалій «чужого» життя або давно відомі реалії нерідко перейменовували вдалим запозиченим словом. Так само й українська мова збагачувалася іноземними елементами і словами"18.

П. Селігей узагальнив основні чинники проникнення запозичених слів: „1) іншомовна термінологія є міжнародною, узвичаєною серед зарубіжних фахівців; 2) тенденція до лаконізму й однослівності: мовці воліють позначити поняття одним запозиченим терміном, аніж багатослівно-громіздким питомим зворотом, замість довгих описів увесь потрібний зміст зосереджується в одному-єдиному слові, від якого до того ж утворюються однослівні похідні; 3) чуже слово однозначне, його семантика більш конкретна й чіткіше окреслена, воно деталізує наявне поняття, вносить новий смисловий відтінок, який важко чи неможливо передати питомим аналогом; 4) деякі іншомовні слова прищепилися в науковій мові через естетичні або етичні міркування; 5) чужі слова жваво проникають і тоді, коли окремі суспільні прошарки захоплюються культурою іншого народу. Тоді запозичення вкорінюються не стільки, щоб уточнити поняття чи прояснити суть справи, скільки з бажання мовця засвідчити свою сучасність і поінформованість, з претензій на розумову або ділову перевагу, з міркувань моди чи снобізму, а також з метою маніпуляції - щоб створити видимість чогось нового чи незвичайного" $"$.

${ }^{13}$ Л.А.Булаховсь ки й, Вибр. праиі, в 5 томах, Київ 1975, т. 1, с. 265.

${ }^{14}$ М.П.Кочерган, Загальне мовознавство, Київ 1999, с. 187.

${ }^{15}$ М. П. Кочерган, Вступ до мовознавства, Київ 2002, с. 229-230.

${ }^{16}$ Див. напр.: С.В.Семчин ський, Взаємодія мов і фактори лінгвістичного розвитку, [в:] „Українська мова і література в школі”, 1973, № 7, с. 25-37.

${ }^{17}$ Див.: І. Кочан, Системність, динаміка, кодифікація слів з міжнародними кореневими компонентами в сучасній українській мові, автореф. дис. ... д-ра філол. наук, Київ 2006, с. 6.

${ }^{18}$ Там само.

19 П. Селігей, Що нам робити із запозиченнями? [в:] „Українська мова”, 2007, № 3, c. $3-17$. 
Явиче мовної взаємодії:

досліднищькі підходи, специифіка трактування, причини

Торкаючись цієї теми, О. Мороховський, відповідно, виокремлює три групи чинників, що зумовлюють процес запозичення: 1. "Номінативна безвихідь" і прагнення до мовленнєвої економії. Зустрічаючись з новою реалією, яка не має спеціального позначення в певній мові, мовець віддає перевагу не описовому звороту рідною мовою, а запозичує його іншомовне позначення. Інколи описовий зворот може бути занадто великий для того, щоб уживатися в процесі щоденного мовного спілкування. 2. Прагнення мовців використати слова, позбавлені будь-яких конотативних значень, головно, у сфері науково-технічної термінології і в номенклатурі. Для створення нових термінів можна використовувати як засоби рідної мови, так і запозичення. Але розвиток терміносистем низки наук у країнах європейського регіону свідчить, що вчені часто надавали перевагу запозиченим засобам перед власними. 3. Прагнення мовців використати слова, яким властиве конотативне значення, головно, у сфері публіцистики і молодіжного жаргону. У публіцистиці, особливо присвяченій іноземній тематиці, іншомовні запозичення вживаються зі стилістичною метою - наблизити, конкретизувати описувані явища для читача i в той же час показати їх іншомовність ${ }^{20}$. Отже, „екстра- та інтралінгвальні чинники перебувають у постійній взаємодії і спричиняють кількісні та якісні мовні зміни"21.

Німецький учений Г. Пауль визначив чинники, що впливають на процес запозичення - це певний мінімум двобічного контакту мов через посередництво міграції груп людей, територіальне розміщення, масове переселення, завоювання, а також подорожі окремих осіб ${ }^{22}$.

Однак лінгвістичні причини запозичень мотивовані потребою в: „(1) поповненні, а то й створенні певної тематичної чи лексико-семантичної групи, недостатньо репрезентованої або відсутньої на певному етапі розвитку мови-реципієнта; (2) семантичному обмеженні питомого слова, усуненні його багатозначності; (3) вищому ступені термінологічної визначеності запозичуваного слова, що склалася в мові-джерелі порівняно з наявними питомими відповідниками; (4) тенденції до вживання одного запозиченого слова замість описового звороту; (5) деталізації відповідного значення, розмежування його смислових відтінків шляхом закріплення їх за різними словами"23.

В українському мовознавстві проблему мовних контактів докладно розробляв Ю. Жлуктенко, який зазначив: „Для того, щоб дві або більше мови почали взаємодіяти, вони повинні до такої міри локально наблизитись одна до одної, щоб між ними встановилися певні міжмовні, або інтерлінгвістичні зв'язки, які прийнято називати мовними контактами"24. Учений поділяе мовні контакти на (1) безпосередні й опосередковані; (2) між спорідненими і неспорідненими мовами; (3) з однобічним і обопільним впливом; (4) маргінальні (на суміжних територіях); (5) внутрішньо регіональні (на одній і тій самій території); (6) казуальні і перманентні (перманентні свідчать про тісні мовні зв'язки, засновані на постійному й тривалому спілкуванні носіїв різних мов. Вони мають

${ }^{20}$ О. М. Мороховський, Деякі питання теорії (іншомовних) запозичень, [в:] „Мовознавство" 1984, № 1, с. 19-25.

${ }_{21}^{21}$ Л. Струганець, Динаміка лексичних норм украӥнської літературної мови XX cm., Тернопіль 2002, с. 95.

${ }^{22}$ Г. Пауль, Принципы истории языка, Москва 1960, с. 440.

${ }^{23}$ С. В. Гри не в, Терминологические заимствования (Краткий обзор современного состояния вопроса), [в:] С. В. Гринев, Д. С. Лотте, Вопросы заимствования и упорядочения иноязычных терминов и терминоэлементов, Москва 1982, с. 149.

${ }^{24}$ Ю. А. Жлуктен ко, Мовні контакти. Проблеми інтерлінгвістики, Київ 1966, с. 135. 
значний вплив на розвиток мов, що контактують; казуальні — це тимчасові або випадкові зв'язки, для яких характерна слабка інтенсивність мовної взаємодії); (7) природні (безпосередне спілкування); (8) штучні (навчання в школі) ${ }^{25}$. Г. Їжакевич доповнює цю систему ще одним пунктом: (9) змішані (природноштучні $)^{26}$.

Отже, на сьогодні в мовознавстві розрізняють зовнішні (екстралінгвальні) та внутрішні (інтралінгвальні) причини запозичень. Власне через них відбувається зв'язок історії мови з історією народу, вони визначають розвиток мовної системи. Зовнішні причини є ефективними в разі їхньої “підтримки" з боку внутрішньої тенденції розвитку мови загалом. Опосередковані та безпосередні контакти між народами - це і є зовнішні причини появи запозичень.

На сьогодні не існує єдиного визначення для понять "мовні контакти" та "взаємодія мов", що засвідчує потребу подальшого вивчення їхніх параметричних ознак.

\footnotetext{
${ }^{25}$ Там само, с. 135.

${ }^{26}$ Г. П. Їжакев ич, Украӥнсько-російські мовні зв'язки радянського часу, Київ 1969, с. 188.
} 